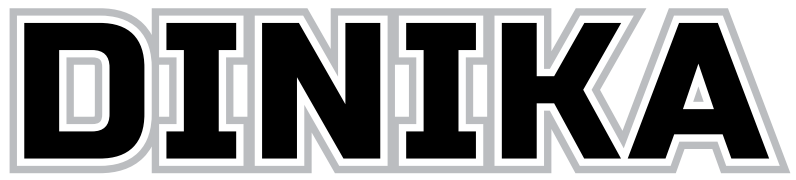

Academic Journal of Islamic Studies

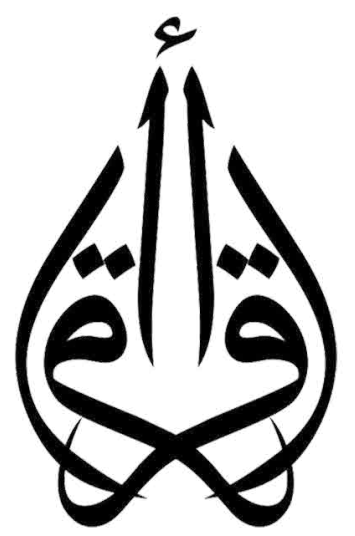


Volume 4, Number 3, September - December 2019 ISSN: 2503-42I 9 (p); 2503-4227 (e)

\section{DINIKA}

Academic Journal of Islamic Studies

\section{Table of Contents}

\section{Main Articles:}

Muslimab Beauty Veiling, Piety and Commodity in the New Indonesian

Public Sphere

Yuyun Sunesti

Competing Identity and Culture: The Formation of Forum Lingkar Pena and Komunitas Matapena in Indonesia

Nor Ismah

Ria Ricis and New Platform of Islamic Popular Culture

Wahyudi Akmaliah

\section{Articles:}

Perseteruan Memori Kolektif Kontestasi Islam dan Politik di

Tasikmalaya Pasca-Orde Baru

Amin Mudzakkir

Qital: Reinterpretasi Pendekatan Humanis

Ana Rahmawati, Azzah Nor Laila

The Characteristics of Philosophical Knowledge of The Qur'an and Prophetic Revelation According to Muni Laswad in His Book Islâm al-Falâsifa

Muhammad Makmun, Dessy Yanti Srie Budiningsih 


\title{
Competing Identity and Culture:The Formation of Forum Lingkar Pena and Komunitas Matapena in Indonesia
}

\author{
Nor Ismah \\ Leiden University \\ email:n.ismah@hum.leidenuniv.nl
}

\begin{abstract}
This study focusses on the genealogy of the Forum Lingkar Pena and Komunitas Matapena movements, which have produced novel Islam remaja (Islamic youth novels) and novel pop pesantren (pesantren popular novels). Using Bourdieu's concept of habitus, I analyze the field where Forum Lingkar Pena and Komunitas Matapena discourses are disseminated, particularly among Muslim youth in Indonesia and how Islamic popular culture is represented through these novels and the dynamic of Muslim youth community in struggling for meaning in the Indonesian literary field in general. This research found that establishment of FLP and Komunitas Matapena can be described through three main ideas. Firstly, these communities encountered the massiveness of popular culture by offering a medium that supports identity formation for Muslim youth. Secondly, there is a link between the idealism promoted by Muslim organization movements and the establishment of FLP and Komunitas Matapena, and this link determines their forms and cultural products. Thirdly, they use popular culture, such as magazines and popular novels, as media to spread and preserve their idealism, targeting young people.
\end{abstract}

\section{Keywords:}

Islamic youth, FLP, habitus, popular culture, identity

\section{Introduction}

The existence of communities and non-formal spaces has an important contribution in the development of writing, reception and 
criticism of literary works in Indonesia. Two literary communities have succeeded in playing an important role in offering reading trends for Muslim youth, namely Forum Lingkar Pena (the Circle Pen Forum) or FLP and Komunitas Matapena (Matapena Community). ${ }^{1}$ Although both communities use pena (pen) for their names, they have different characteristics and backgrounds. In this paper, I argue that the FLP and Matapena movements are determined by their economic, cultural, social, and symbolic capital in which they have their strategies and forms for spreading their messages and ideas through literary products and their organizations. Both of them play a significant role in producing Islamic popular culture and educating young people in forming their identity and thoughts about being a good Muslim.

I begin this paper by identifying the social-historical background of traditional and modern Islam in Indonesia from 1960 through 2000 to understand the genealogy of the FLP and Komunitas Matapena. Then, I shift attention to the FLP and Komunitas Matapena, which produce novel Islam remaja (Islamic youth novels) and novel pop pesantren (pesantren popular novels). ${ }^{2}$ Using Bourdieu's (Bourdieu 2007) concept of habitus, I analyze the field where Forum Lingkar Pena and Komunitas Matapena discourses are disseminated, particularly among Muslim youth in Indonesia. Finally, I examine how Islamic popular culture is represented through these novels and the dynamic of Muslim youth community in struggling for meaning in the Indonesian literary field in general.

1 Forum Lingkar Pena means the Circle Pen Forum, while Matapena means the Tip of a Pen.

2 "Popular youth novel" refers to novels that deal with and appeal to the needs of youth, including, usually, themes that tell about love, and using language that does not obey the patterns of serious language. In regard toMuslim popular youth novel in Indonesia, there are two different genres and are determined by the story told by the novels. First, novel remajaIslami (Islamic youth novel) is used for a novel that describes young Muslims in urban areas, and second, novel pop pesantren (pesantren popular novel), which tells of a young Muslim who lives at pesantren. This style of novels is also a strategy of marketing in order to target particular readers who are interested in this type of story.

DINIKA, Volume 4, Number 3, September - December 2019 


\section{Theory of Analysis}

Theoretically, my analysis is guided by Pierre Bourdieu's (Bourdieu 2007) social theory. His social theory works on the idea that a social fact, such as a community movement cannot be separated from human thought, passion, and intervention. He said, "All of my thinking started from this point: How can behavior be regulated without being the product of obedience to rules?" (Bourdieu cited in Maton 2008:50). Three main mechanisms of Bourdieu's theory are the concepts of babitus, field, and capital. Habitus is "a social subjectivity" and "the social embodied" meaning that links the social and the individual because every individual has unique experiences that means they can be distinguished from others in their community with the same social class, gender, ethnicity, sexuality, occupation, nationality, region, and so forth (Maton 2008:53). Habitus includes perception, appreciation, decision, and action that are inherent in human life as a result of a period of internalization, either with awareness or without. Habitus then interacts with different habitus, and they link to each other in the field, which Bourdieu defines as "a separate social universe of its laws of functioning independently of those of politics and the economy" (Bourdieu 2007:89). In the field, capital, including economic, cultural, social, or symbolic capital is very significant because it determines the field of power.

In terms of the literary field, Bourdieu defines it as "an independent social universe with its own laws of functioning, its specific relations of force, its dominants, and its dominated, and so forth," and hence, "literary works are produced in a particular social universe endowed with particular institutions and obeying specific laws" that are called "cultural production." According to Bourdieu, novels or any other literary works are considered a distinctive property that can be linked to each (Bourdieu 2007:90), but they have reciprocal connections to the social universe that position them within the literary field as part of the social culture (Bourdieu 2007:92). It 
is the literary field in which FLP and Matapena struggle for meaning and Bourdieu's concepts can be used as thought instruments in reading and analyzing the phenomenon of the FLP and Matapena movements to find their position and meaning and locate them in a broader social context in Indonesia. Based on this idea, this study considers that individuals determine the goal and objective of one community, and therefore this connection can explain why communities produce their cultural productions and how the dynamic of their position and the relativity of values is associated with the interconnectedness between field and capital.

\section{A Brief Overview on the Growth of Muslim Organization in Indonesia during the New Order}

The emergence of Forum Lingkar Pena and Komunitas Matapena cannot be separated from the social and political context during the New Order from 1965-1998. The government controlled people's freedom to express ideas and opinions by centralizing the bureaucratic system and restricting mass media and organizations (Sen and Hill 2000:219). For example, in 1982 the government banned Tempo magazine for the first time due to their critical report on a Golkar (Golongan Karya; the government party) campaign event that led to a commotion (Khairuddin 2007). The government also took a role in the PDI (Partai Demokrasi Indonesia; Indonesian Democracy Party) organization structure by not recognizing the leader selected in the election, who was Megawati Sukarnoputri and repositioning her as the government delegate (Sen and Hill 2000:6).

However, in 1998 the New Order collapsed after practically four decades of controlling Indonesia under an authoritarian system. Subsequently, people were excited about democracy and freedom of expressions. As a result, many political parties emerged and participated in the 1999 elections, and those parties tend to reproduce "primordial loyalties," which are "class, ethnicity, and religion" (Woodward 2001:30). 
Van Bruinessan (2002:118) also notes the emergence of radical Muslim groups in modern Indonesia, and argues that these groups can be linked to roots in the Darul Islam movement and the Masyumi party, which are considered to be the two relatively "indigenous" Muslim political movements of the 1940s, and to some other recent transnational Islamic networks.

It is noteworthy that Islamic organizations in Indonesia emerge in many different forms and orientations, and they move and create collaboration bytheir respective fields. According to Woodward (2001:30), the Indonesian Muslim community can be divided into five basic religious orientations. First is indigenized Islam, which considers Islam as a component that integrates with the more extensive cultural system. Hence, there is an amalgamation of ritual and religious belief that forms a very local Islam; for example, Islam Jawa or Javanism. They practice many elements of Islamic mysticism. To conduct significant rituals like weddings and funerals, Javanists need the assistance of more educated and learned Muslims, but they distrust what they believe to be the Islamist. Second is the traditional Sunni Islam, in which Nahdlatul Ulama is embedded in the study of the classic legal, theological, and mystical texts, and represents the traditional ulama (Islamic scholars). Nahdlatul Ulama (NU), literally meaning "Renaissance of the Ulama," organizes over thirty million members, positioning it as the largest Muslim organization not only in Indonesia but in the world. Founded in 1926 by Hasyim Asy'ari, NU's purpose is promoting and defending Sunni Muslim traditionalism to respond to the Wahabi and Islamic fundamentalism in the Netherlands Indies. NU is closely affiliated with a vast network of pesantren (Woodward 2001:30-32), which is considered the oldest education system in Indonesia and is mostly located in a rural area (Noer 1973:300). NU has been of some account in Indonesian cultural and political movements. At the beginning of the republic, NU was associated with the pan-Islamic political party 
Masyumi, and in 1952 it became an independent political party. In 1984, NU then declared itself a religious and social organization and deserted active involvement in politics (Woodward 2001:32).

The third is Islamic Modernism; one of its representatives is Mubammadiyah, established in 1912 by KH. Ahmad Dahlan in Yogyakarta. Unlike Islamic traditionalists, Modernists usually live in urban areas, and only accept the legitimacy of the primary texts of the Islamic tradition, which are the Quran and the Hadith (the traditions of the Prophet Mohammed). Emerging in Indonesia at the turn of the twentieth century, Modernism promotes Islamic purification and argues against mysticism and the ritual practices related to it(Woodward 2001:33). According to Woodward (2001:33), most of Muhammadiyah theological and political philosophy can be traced to the thought of Mohammed Natsir (19081993). Natsir was one of the prominent figures in Persatuan Islam (the Unity of Islam), which contributed most of Muhammadiyah's theological agenda in terms of political struggle, and in explicitly establishing an Islamic state. Natsir was the initiator in creating the da'wa movement in which he determined to dedicate their passion for da'wa (proselytizing of Islam) rather than political practices. The neglecting of the Jakarta Charter in 1959 was one of the background reasons that proved to them that most of the nation's Muslims, almost 90\%, did not agree with the rule of living by the sharia (Islamic) law. The DDII (Dewan Dakwah Islamiyah Indonesia; Indonesian Islamic Da'wa Council) was established by Natsir and his friends in 1967. This council was concerned with "missionary efforts" among Indonesia's Muslims, proposing to form them into better Muslims (Bruinessen 2008:122).

The Fourth are Islamist groups that support "a highly politicized and anti-Western interpretation of Islam" (Woodward 2001:31). They are mostly found in university campuses and large urban centres. They are involved with the global Muslim discourse focused on jibad and shariah law. 
Like Islamists elsewhere, they concur in their views of global politics, such a belief in Western attempts to annihilate Islam and that the only solution to the problem is establishing nation-states based on shariab law and global Islamic collaboration. According to Bruinessen (2008:144), the most energetic of them are the Majelis Mujabidin, the Darul Islam movement that has emerged from the underground, and the Laskar Jihad, which appeared in early 2000 from the most extreme branch of the Islamic students' movement. And finally, the fifth is neo-modernism that figures out Islamic foundations for many appearances of modernity, including democracy and cultural pluralism. Neo-modernism refers to "a new development." Neo-modernist thinkers and NGOs hold opposing views significantly different from both Islamists and modernists. They disagree with the belief that the establishment of Islamic institutions determines economic and social progress. They hold Muslim values and ethics rather than living by shariah law. Indonesian neo-modernists emerge from both modernist and traditionalist backgrounds (Woodward 2001:35).

This historical background of Muslim organization movements in Indonesia shows that Muslim organizations are connected both with the political and the social-cultural context. As concluded by Bruinessen (2008), "the nature of Muslim political movements in Indonesia appears to be a response to the changing political environment (and the availability of foreign funding) rather than to some inherent internal dynamic. Transnational networks -along which people, money, and ideas move - have become extremely important." (149). Also, the emergence of some people or social agents from Muslim organizations shows us that a community movement cannot be separated from human thought, passion, and intervention. 


\section{The Rise of Popular Youth Culture}

Coinciding with the dynamic growth of the Muslim organization movements in Indonesia, the economy was growing, and the society and culture were also changing. Heryanto (2008:6) notes that Indonesian industrialization expanded extensively only in the 1980s due to the strength of the military rule of the Suharto regime, a close partner of the Western bloc during the Cold War. Sen and Hill (2000:221) mention that two main factors influenced the rise of popular culture in Indonesia, which are the Reformation era and the massiveness of market industrialization in Indonesia in the 1980s. The reformation era signifies the democratic political system and a tightening of the economy. Thus, the political change led to new opportunities for the media market, such as the ability to publish without first getting permits and the legalization of cable television, while cultural plurality was supported as a political priority of the post-Suharto government.

Explaining the term "popular culture," Heryanto (2008:6) writes that it is "a product of an industrialized society where both the signifying practices and their observable products (i.e., culture) are produced or performed in a great number," thus; popular youth culture has young people as recipients and targets. Youth are typically at the end of their secondary education and are beginner readers who are starting to be adult readers. They are positioned in a free period and are growing as adolescents, developing physically, cognitively, socially, and psychologically (Latrobe 2009:4). In the Indonesian context, youth are targeted by cultural products such as magazines, books, movies, and music.

In the 1970s, some popular magazines that targeted teenagers were published, such as Kawanku in 1970, Gadis in 1973, and followed by Aneka Yess! in 1992. Through the magazines, Indonesian teenagers were introduced and then constructed by popular culture that is closely associated with Western culture. The content of these magazines included up-to-date 
fashions, music, movies, celebrity gossip, and printed advertisements, and all of these kinds of materials become trendsetters in determining the social world of youth in Indonesia (Handajani 2008). In terms of books, a serial novel titled Lupus, written by Hilman Hariwijaya was published for the first time in 1986, and it electrified young readers with its use of prokem language (slang) (Sen and Hall 2000:33). At the same time, Gola Gong and Zara Zettira also published their novel remaja (youth novel). However, in 1990 the novel remaja had to compete with Indonesian private television companies in providing story entertainment; the government created a policy that local drama, sinetron, should be prioritized (Salam 2002:2). In addition to novels, since the early 1980s, youth readers have been supplied with American comics, and Japanese cartoons such as Dragon Ball and Doraemon emerged in the 1990s, as well as movies based on these comics that have played on some Indonesian private television stations (Sen and Hall 2000:30 and 121).

In terms of Islamic narratives, as noted by Hefner (1997:90), the 1980s was a period when Islamic stories obtained their popularity in Indonesia. The trend was signified by the renewal of Islamic thinking with the growth of modernist Islam and the decline of Javanism. In the 2000s, the narrative culture in Indonesia was developing more with the emergence of the new genres of chick-lit and teen-lit (teen literature). This emergence was led by the translation and publication of Western chick-lit into Indonesian in 2003, with Helen Fielding's Bridget Jones's Diary, ${ }^{3}$ published in Britain in 1999, being the first chick-lit translated into Indonesia (Arimbi 2009:83). According to Chicklit.us (Ferriss 2006:3), chick-lit "reflects the lives [of] everyday working young women and men, and appeals to readers who want to see their own lives in all the messy detail, reflected in fiction

3 This novel tells about a woman who is thirty-something years old and worries about her love life, career, and some bad habits including smoking and drinking, but she struggles in her life. Suzanne Ferriss and Mallory Young, Chick Lit: The New Woman's Fiction (New York: Routledge, 2006), p.2. 
today." Compared with chick-lit, teen-lit describes a teenager's lifestyle, including school life, sweet seventeen parties, family, and love, and it is, therefore, addressed to teenager readers. Substantively, chick-lit and teenlit are the same as the previous novel remaja but, with the growth of this genre, several new writers, including young Muslim writers, have emerged, publishing their first novels in which they share their own experiences (Kurnia 2007).

Popular culture has many strategies in appealing to youth consumers, and at the same time, they form the social world of youth according to dominant cultures, which are Western. Starting from this point, FLP and Matapena are two communities that also target youth as members and readers but to empower them in creating their own culture. However, since FLP and Matapena may have different roots, this influences their forms and the culture that they present.

\section{Inspiring People}

Within the massiveness of popular culture, some social agents enabled factors that led to the establishment of FLP and Matapena. Considering Bourdieu's thinking tools, FLP and Matapena are fields where collections of habitus are connected and reciprocate with one another to gain capital for struggling for meaning in a larger field that includes youth movements and the Indonesian literary field. Among the people who can be called social agents, two famous and much-chronicled champions of the youth communities are Helvy Tiana Rosa with Forum Lingkar Pena and Akhmad Fikri AF with Komunitas Matapena.

\section{Helvy Tiana Rosa}

Helvy is a productive writer and a prominent literary activist in Indonesia. She began her career as a writer by writing poetry as a child and short stories as a teenager. She was born in Medan, North Sumatra 
on April 2, 1970. After finishing her secondary and tertiary education, she moved to Jakarta and continued her schooling. She went to University Indonesia in Arabic literature for her BA and gained her MA from the same university in Indonesian literature. In addition to writing, her activities include theatre; she founded a contemporary Muslim theatre in 1991 when she was an undergraduate. She also was involved with the da'wa campus movement during that time, ${ }^{4}$ and from this activity, she and her friends established FLP on February 22, 1997 (Rosa n.d.; Arimbi 2009:99; Arnez 2009:48). Her personal aim, which is part of FLP's da'wa, is "to recruit new members for FLP, preparing young writers concerned with da'waissues for the challenges of globalization" (Arnez 2009:49). Currently, FLP has its house publication, and with 5,000 members in 120 branches in various Indonesian cities and overseas, FLP has published approximately 3,000 books written by its members (Rosa 2011; Arimbi 2009:100).

To use Bourdieu's concepts of habitus and field, FLP is a field that resulted from the synergy of a collection of habitus, including Helvy Tiana Rosa's habitus. She has cultural capital, which is her achievement in education and her career as a writer; social capital, which is her network among da'wa campus and literary activists; and symbolic capital, which includes her charisma and position due to her achievement in education and as a writer. These different kinds of capital may have led her to control economic capital, which enabled her to establish the FLP house publication. Also, since fields rely on habitus, Helvy and her friends have determined the form of the FLP movement based on their embodied and internalized thoughts and life experiences. Thus, it can be said that the form of the FLP movement as a da'wa movement by pen has been

4 In the 1990s, student movements such as da'wa campus gained their popularity (Annida 2008). Bruneissenwrotes, "Another influence that became perceptible on some campuses in the 1990s was that of the extremely puritan Islam of Wahhabi Ulama in the Arabian peninsula or, as its followers preferred to describe it to themselves, 'Salafi Islam'.'Martin van Bruinessen, "Genealogies of Islamic radicalism in post-Suharto Indonesia," South East Asia Research 10, 2 (2002)p.134. 
associated with Helvy'sskills, activities, and career and these will appear as well in FLP products and programs.

Also, by establishing and being involved with FLP, Helvy gains more power since she owns morecapital. As a founder, she becomes a leader in FLP and is acknowledged by people. In 2003, she became a secretary of the Jakarta Arts Council (DKJ) and was a member of its literary committee from 2003 to 2006. She has won a number of awards and competitions for reading, poetry, and short stories, at both the provincial and national levels, such as the Pena Award in 2002, the "TokohPerbukuan Islam" award from the committee of the Islamic Book Fair (IBF), and the prize for the Appreciation for the Achievement of Indonesian Women by Tabloid Nova and the Indonesian Ministry for Women's Empowerment in 2004 (Arimbi 2009:100; Arnez 2009:5). Reciprocally, due to Helvy's achievement, FLP becomes more stable and acknowledged. It has more power for struggling for meaning in a broader context of Indonesian literature.

\section{Akhmad Fikri AF}

Fikri is a writer and an activist in book publication and the Indonesian literary world. He was born on January 9, 1972, in Tangerang, West Java. Coming from a family that is culturally close to NU, Fikri lived in a pesantren in Kreo, Tangerang from 1983 to 1987 and in the Pesantren Darunnajah Jakarta from 1987 to 1990 . He gained his BA from the IAIN (Institute Agama Islam Negeri) or State University for Islamic Studies in Yogyakarta. It was in 1991 that he started becoming involved with the student cultural movement in which he made friends such as Imam Aziz, Ahmad Suaedy, and Jadul Maula while conducting street discussions on democracy, Islamic studies, and human rights. Later, in 1993, these group discussion become LKiS (Lembaga Kajian Islam dan Sosial), or Institution of Islamic and Social Studies, marked by the publication of Kiri Islam 
("Islam's Left"). This book was translated from Al-Islam al-Yasar, written by Kazhuo Shiogaki, which discussed the philosophy of Hassan Hanafi, an Egyptian scholar. With the NU generation, LKiS spread the spirit of pluralism and commitment to pesantren values and tradition, which are tasamub (tolerance), tawazun (balance), ta'adul (justice), and tawasuth (moderation) (LKiS 2008; Rahman and Shoffan 2010:130).

After many years working with pesantren issues and book publication, he realized that something was missing from the euphoria of popular culture and the book industry which were local values and the cultural wisdom that is rooted in Indonesian culture. He found that the phenomena of Indonesian chick-lit and the Islamic youth novel are not associated with Indonesian culture, with the former more Western and the latter closer to Islamist groups and Arabism. Therefore, he initiated the establishment of Matapena as a branch of LKiS house publication to facilitate young pesantren writers in sharing their experiences and creating balance in the popular culture market with pesantren and local perspectives. ${ }^{5}$ Through his cultural capital, which is his education and skills in book publication; his social capital, in which he has connections with pesantren and publication networks; and his symbolic capital, which is his position as a director of the LKiS house publication, Fikri implemented his thoughts by establishing Matapena in 2005. Currently, Matapena has published 38 books and maintains 1,313 members in 37 branches located in pesantren or other institutions such as madrasah (Islamic schools), public schools, and local organizations that are coordinated with IPNU (Nahdhatul Ulama Student Association) (Matapena 2011).

There is also a reciprocal connection between Fikri as habitus and Matapena as a field, which was also the case when he became involved with LKiS group discussions. Fikri has written and edited many books on democracy, pesantren, and local values. Three of them are Menjadi Politisi

5 Email, November 22, 2011. 
Parlementer ("Becoming a Parliamentary Politician," 1999), Tawashow Pesantren ("The Laugh Show of Pesantren," 1999), and Negeri Kong Draman ("Kong Draman's Country," 2009). He was the chairperson of AnshorNU (Nahdhatul Ulama youth organization) and IKAPI (Ikatan Penerbit Buku) or the Association of House Publications in the Yogyakarta region. ${ }^{6}$ His cultural and symbolic capital also will benefit Matapena in struggling for meaning in the Indonesian literary movement.

\section{The Identity Formation of Being a Good Muslim}

Emerging from different cultural roots, FLP and Komunitas Matapena attempt to play roles in shaping young Muslim identity in Indonesia. This effort can be seen from their mottos, the terms and language they use, and the themes of their narratives.

\section{Smart, Sociable, and Pious}

FLP has since June 2000 been associated with the Ummi Group which publishes the magazines Annida, Ummi and Saksi. Soon after its foundation FLP had an effective outlet for its authors through Annida, the Ummi Group's magazine for teenage girls. First published in 1991 by PT Kismus Bina Tadzkia, it targets young Muslims as its contents are predominantly Islamic short stories that stress ethics and identity (Rijal 2005: 430). Moving away from previously overt missionary articles of the Ummi Group, Annida uses fiction as an instrument for proselytizing as it was considered more likely to engage its readers (Latifah 2006: 6). Its circulation of almost 100,000copies each month is proof of its receptivity (Rosa 2003: 43).

Annida magazine was the first publication of FLP in 1991 (Kailani 2006), and it continued until 1993. Annida's early motto was "The Call from Islamic Women"(Kailani 2008). The motto attempts to explain the

6 Ibid.

DINIKA, Volume 4, Number 3, September - December 2019 
meaning of Annida itself, which comes from an Arabic word meaning "call." Thus, "calling" means "calling for Muslim teenagers to understand and implement Islamic values in the modern context" (Kailani 2008:8). From 1993 to 2000, the motto changed to "The Series of Islamic Stories," followed by "Youth's Friend to Share Stories" in 2000-2003. After this period, the motto became "Smart, Friendly and Pious" (Kailani 2008:8). This motto shows that Annida attempted to combine the personal quality of being a smart person with the social condition of being friendly (considering the current codes of youth sociability) while keeping on track as apious Muslim. The message from the slogan may say: Tobe a good Muslim, be sociable and follow the shari'a. Finally, the latest motto is "Endless Inspiration," which started in 2007 (Annida 2008).

The message of gaul tapi shar'i (be sociable and follow the shari'a) can be found in the language the magazine uses, as well as the theme of narratives in the magazine. For example, in terms of language, besides using the actual bahasagaul (the expression of sociability) such as bikin means "make" and cling means "clean" (Annida 2008), Annida also combines Indonesian and Arabic words, for example, jaiz or jagaizzah means "keep dignity", nyar'i dan trendy means "pious and trendy", haraki means "suggest to move" (Kailani 2008:8). Some Arabic words are often used as well, such as ana (I), antum (you), ikbwan (brother), afwan (sorry), murabbi (educator) (Annida 2008:21). In this case, language can be a symbol that represents the culture of the speaker or the origin of the language. Arabic is the language of the holy Qur'an, so by using Arabic, Annida expresses itself as an Islamic magazine. In terms of the theme of narratives, Annida inserts da'wa messages in its short stories and some articles, such as inviting people to wear veils (Kailani 2008:8) and positioning shari' $a$ as the most significant code in the messages (Latifah 2006:7).

An example is a short story "Ketika Mas Gagah Pergi" (When Gagah Passed away) written by Helvy Tiana Rosa. The theme is Gita's decision to wear the jilbab (headscarf). Kailani (2008:9) describes: 
It's open with Gita's confusing about her brother named Gagah ... Gagah has been changed. He starts to wear koko or baju takwa (a cloth that usually wears for shalat), maintains his beard, listens to the nasyid (various kinds of pop and hip-hop music which are associated with Islamic music) and attends pengajian (Islamic preaching). ... Gita then consults about Gagah's change to her friend Tika, who currently decides to don the headscarf. When she heard about Gagah's change, Tika was happy and told to Gita that her brother became ikbwan a title for someone who involves in RohisorKerohanian Islam (Islamic Studies groups). The story is closed during Gita's birthday when Gagah passed away within an accident ... Although Gagah yet come to its Gita's valuable moment, he presented a special gift for her, namely a green long veil and headscarf.

In addition, since FLP is associated with urban culture, most of the novels (novel remaja Islami or Islamic youth novels) it publishes tend to tell of the conflicts, characters, and settingsthat represent urban experiences, such as conflicts of broken homes, drug consumption, parenting problems due to lack of attention, and so forth. However, in some parts, they still deliver the story from the da'wa perspective. For example, there is a story on Kelana and her stepmother in a novel titled Rumah Cinta Kelana (The Love House of Kelana) written by SofieDewayani. ${ }^{7}$ Kelana does not wear a veil, she was close to her father who already passed away, and she prefers to spend her time in her room instead of having fun such as shopping or engaging in other forms of youth sociability with her friends. Her problem is to find true love and attention from her family. Then she meets her father's second wife, someone who makes an impression on her in terms of being a good Muslim by following an Islamic code of conduct and wearing a veil. Kelana is considered a Muslim beginner, and she will learn

7 This novel won the novel-writing competition conducted by theMizanPublishing Company in Indonesia in 2002. Mizan is an acknowledged Islamic book publisher and has produced a number of best-selling books including novel remajaIslami. 
how to pray and read the holy Qur'an from her stepmother (Dewayani 2002:164). Thus, this story says that one of the accomplishments related to youth identity as a Muslim female is to wear aveil. Indeed, this theme relates institutionally to FLP, which promotes and declaresits community as da'wa by pen.

\section{Pesantren Values:Tolerance, Balance, Justice, and Moderation}

According to Matapena's motto, which is Matapena Hati Pesantren (Matapena, the Heart of Pesantren), "Matapena attempts to create and develop literacy culture among youth by exploring values and traditions that are originally from the pesantren to enrich literary treasures of Indonesia" (Matapena 2011). Thus, Matapena emphasizes the details of localities associated with pesantren such as the language used, daily life activities, and santri sociability. Unlike FLP, which publishes a magazine, Matapena publishes novels in the novel pop pesantren genre (pesantren popular novel) and collections of short stories. In delivering the stories,Matapena use bahasa gaul (language of sociability), Arabic language that refers to language used in the pesantren textbook that is called kitab kuning (literally "yellow book"), and some words used in the pesantren such as ta' 2 ir (punishment), ro'an (cleaning work), and ghashab (using other's property without permission) (Ismah 2011:3).

Indeed, Matapena seems to target a narrower group of readers than FLP, since the stories written in Matapena are about pesantren. People who do not know about pesantren cannot connect what they read to what they know, and it may be difficult for them to understand the story. However, Matapena may act as a bridge to connect outsiders with Pesantren insiders (Ismah 2011:1), and this is what Fikri thinks about sharing experiences that have roots in Indonesian culture instead of Western or Arabic culture. Because Matapena pays attention to emerging pesantren values by telling daily life stories of the pesantren, novel pop pesantren eliminates the term 
da'wa. By "spreading ideas on pesantren literature that are distinctive and appreciative of the values of tasamuh (tolerance), tawazun (balance), ta'adul (justice), dan tawasuth (moderation)", novel pop pesantren have shared the Islam itself to the readers (Matapena 2011).

A good example is a novel titled Jadilah Purnamaku Ning (Be My Moon, Ning), written by Khilma Anis. This novel tells about Nawang Wulan and her love story with a son of a leader of a pesantren. She attempts to prove to her mother that Alvin, her boyfriend, is not like her father, who has rejected her mother due to her low status, as she came from an average family. However, Nawang is facing the same experience. When she is visiting and being introduced toAlfin's family, she is rejected by the family. Nawang argues:

"You can despise me, but not my mother. You might hate her past, but you must know that she did that only because she had to defend her life. Your self-recognition as Allah's servant is useless because your mind is dirty. Allah always behaves equally to us. Don't you think that you are nothing?" (Anis 2008:91).

This story shares justice and tolerance values that should be implemented by those who acknowledge themselves as Muslims. Thus, this novel is not just telling the symbol of a Muslim such as wearing the veil and the Holy Qur'an recitation, but the substantial value of Islam. Another example is Tarian Cinta, a novel written by Maia Rosyida. According to the author, the book attempts to say that "Islam recognizes and supports difference and freedom of choice.” (Ismah 2011:110). Dahlia, the main character in the novel, is a teenager who works as a dancer to support her family. However, some conservative kiai (the leader of pesantren) attack her and claim that she is an inhabitant of hell. The novel then introduces Mbah Jalaluddin, a wise kiai, who speaks for and defends Dahlia (Rosyida 2007).

DINIKA, Volume 4, Number 3, September - December 2019 
The themes that emerge from FLP and Matapena literary works lead me to conclude that literary works can appear with many different forms and messages according to the ideology of the writer, institution, or any specific social universe.

\section{Popular Literature and the Struggle for Meaning in the Indonesian Literary Field}

The emergence of popular youth novels in Indonesian leads to the rise of criticisms and comments about the books. First, some criticisms relate to the quality of the stories, since popular novels tend only to fulfill the demand of the reader market, which in this case is the youth. As a result, the novels follow the same patterns and themes, with very few demands on creativity (Sumarjo 1982:18). There was even a genre calledroman pitjisan or "trashy romance" in 1959 referring to popular literature, as stated by R. Roolvink (Salam 2002:1). Second, there is a struggle to determine the terms, names, and definitions for these works, such as novel remaja Islami (Islamic youth novel), novel pop Pesantren (pesantren popular novel), sastra kota (city literature), sastra lokal (local literature), and so forth. Some critics argue that the naming of the works such as novel remaja Islami and novel pop pesantren, is just a name and does not necessarily represent as the true Islamic or Pesantren works. In addition, literature does not need any name because its values, such as Islamic values, pesantren values, and locality will appear by themselvesin the literature if the writer has a strong embracement with the values (Thahar 2008).

When FLP emerged for the first time promoting the idea of novel remaja Islami, some literature critics doubted and questioned its ability, legitimacy, and sustainability. Questions also have been asked about Matapena regarding its design of novel pop Pesantren in term of labelling and positioning. There is a debate among pesantren writers regarding the term sastra pesantren (pesantren literature), in comparison with sastra Islami 
(Islamic literature), since both of the labels have an association with Islamic values (Sarmili2011). However, according to Yudha (2008), a practicing publisher, names are needed to explain and position any movements. A label is an identity that differentiates one community from others so that people can recognize them easily. An example is FLP itself. Although doubts and critics remain, FLP has shown their position in Indonesian literary field standing with novel remaja Islami, and this is again determined by the collection of habitus and capitals in FLP field.

The struggle for position and existence relates to how active the community is and what power it has, and it relies on the dynamic of habitus in the community, even letting these communities create a new label and promote it ina larger field. For example, when all of the members of Matapena can show the meaning of novel poppesantren through their novels, meaning that they have more symbolic capital than before, obviously people will acknowledge the community and the label without any doubt. Moreover, if this label relates to "a product of an industrialized society" (Heryanto 2000:6), the more we have the power to influence people, the better we can own our position firmly in the field.

\section{Conclusion}

Based on the previous discussion, I conclude that the establishment of FLP and Komunitas Matapena can be described through three main ideas. Firstly, these communities encountered the massiveness of popular culture by offering a medium that supports identity formation for Muslim youth. Secondly, there is a link between the idealism promoted by Muslim organization movements and the establishment of FLP and Komunitas Matapena, and this link determines their forms and cultural products. Thirdly, they use popular culture, such as magazines and popular novels, as media to spread and preserve their idealism, targeting young people. 
The process of struggle for meaning and the connection between the fields in the broader field will be dynamic, and it is determined by habitus. This connection means that people's interests relate to the capital they have. For those who have lived in the pesantren, and therefore have cultural capital, for example, they might tend to be involved with Matapena rather than FLP, since FLP is associated with Islamists, although this is not absolute. It is also possible that FLP would transform into a traditional Islamic movement as long as the habitus in the community tended to move in that direction. Here, again, it shows that habitus is dynamic and is an element of the underlying field.

\section{References}

Annida. 2008. “Apa Kabar Fiksi Islami.” No.7/xvii March.

Anis, Khilma. 2008. Jadilab Purnamaku, Ning. Yogyakarta: Matapena.

Arimbi, Diah Ariani. 2009. Reading Contemporary Indonesian Muslim Women Writers: Representation, Identity and Religion of Muslim Women in Indonesian Fiction. Amsterdam: ICAS Publications Series, Amsterdam University Press.

Arnez, Monika. 2009. "Dakwah by The Pen". Indonesia and the Malay World 37:107, pp. 45-64.

Azra, Azyumardi, Dina Afrianty, and Robert W. Hefner. 2007. "Pesantren and Madrasa: Muslim Schools and National Ideals in Indonesia." In Schooling Islam: The Culture and Politics of Modern Muslim Education, ed. Robert W. Hefner and Muhammad Qasim Zaman. Princeton: Princeton University Press.

Bourdieu, Pierre. 2007. "Field of Power, Literary Field, and Habitus." in The Cultural Studies Reader Third Edition, ed. Simon During. New York: Routledge. 
Bruinessen, Martin van. 2002. "Genealogies of Islamic radicalism in postSuharto Indonesia.” South East Asia Research 10, 2, pp. 117-154.

Dewayani, Sofie. 2004. Rumah Cinta Kelana : Cerita Remaja. Bandung: Mizan. Ferriss, Suzanne, and Mallory Young. 2006. Chick Lit: The New Woman's Fiction. New York: Routledge.

Handajani, Suzie. 2008. "Western Inscriptions on Indonesian Bodies: Representations of Adolescents in Indonesian Female Teen Magazines." Intersections: Gender and Sexuality in Asia and the Pacific 18, October.

Hefner, R. 1997. "Islamization and democratization in Indonesia". In Islam in an era of nation-states. Politics and religious renewal in Muslim Southeast Asia, ed. Robert W. Hefner and Patricia Horvatich. Honolulu: University of Hawai'i Press, pp. 75-127.

Heryanto, Ariel. 2008. "Pop Culture and Competing Identities" in Popular Culture in Indonesia, Fluid Identities in Post-Authoritarian Politics, ed. Ariel Heryanto. New York: Routledge.

Ismah, Nor. 2001. "The New Generation of Women Writers from the Pesantren Tradition in Indonesia." Explorations 11 no. 1, pp.106-20.

Kailani, Najib. 2008. "We Are The Mujahidin Armed With Pens: The Da'wa Movement of Forum Lingkar Pena in Indonesia." A paper presented in the $3^{\text {rd }}$ Singapore Graduate Forum on Southeast Asia Studies, 28-29 July. Asia Research Institute, National University of Singapore.

Khairuddin, Fahrul. 2007. "Sejarah Majalah Tempo: Konflik dan Pembredelan." in Kompasiana http://sejarah.kompasiana. com/2011/01/07/sejarah-majalah-tempo-konflik-danpembredelan/ (accessed 25 November 2011).

Kurnia, R.S. 2007. "Teenlit Sebagai Cermin Budaya Remaja Perkotaan Masa Kini.” Pelitaku. http://pelitaku.sabda.org/teenlit_sebagai_ cermin_budaya_remaja_perkotaan_masa_kini (accessed 25 November 2011) 
Latifah. 2006. "Writing the self, ascribing Islam. Islamic teen fiction: reforming the Muslim identity." Paper presented at ARI 4th Graduate Workshop on 'Asian Entanglement, Religion and Technology in Contemporary Asia', 19-20 January, National University of Singapore.

Latrobe, Kathy Howard, and Judy Drury. 2009. Critical Approaches to Young Adult Literature. New York: Neal-Schuman Publisher.

LKiS. 2008. "Sejarah LKiS"

ht t p : / / lkis.co.id / index.ph p ? o p t i o n = com content\&view $=$ article $\&$ id $=44 \&$ Itemid $=85 \quad($ accessed $\quad 25$ November 2011).

Matapena. 2011. "Brochure”. Yogyakarta: Matapena.

Maton, Karl. 2008. "Habitus." in Pierre Bourdieu: Key Concepts, ed. Michael Grenfell. Durham, GBR: Acumen.

Noer, Deliar. 1973. The Modernist Muslim Movement in Indonesia 1900-1942. Kuala Lumpur: Oxford University Press.

Rahman, Budi Munawar- and M. Shofan. 2012. Sekularisme, Liberalisme, and Pluralisme. Jakarta: Grasindo.

Rosa, Helvy Tiana. 2011. "Profile" 08 Agustus http://forumlingkarpena. net/profil/ (accessed 25 November 2011).

Rosa, Helvy Tiana. 2011. "Profile" http://helvytr.multiply.com/ profile?\&show_interstitial $=1 \& u=\% 2 F$ profile (accessed 24 November 2011)

Salam, Aprinus. 2002. "Posisi Fiksi Populer Di Indonesia." Humaniora UGM XIV No. 2.

Sarmili, Linda. 2011. "Memaknai Sastra Religius dari Pesantren." Suara Karya Online 12 March. http://www.suarakarya-online.com/news. html?id=274390 (accessed 26 November 2011).

Sen, Krishna and David T. Hill. 2000. Media, Culture and Politics in Indonesia. New York: Oxford University Press. 
Sumarjo, Yakob. 1982. Novel Populer Indonesia. Bandung: Nur Cahaya

Thahar, Harris Effendi. 2008. "Fiksi Islam Hanya Sebuah Label." Annida no.7/xvii March.

Woodward, Mark R. 2001. "Indonesia, Islam, and the Prospect for Democracy." SAIS Review, volume 21, no. 2, Summer-Fall.

Yudha, Andi. 2008. "Tak Ada yang Mengawasi Mutu Fiksi Islami." Annida no.7/xvii March. 